(c) Elsevier/INRA

Original article

\title{
Latitudinal clines of allelic frequencies in Mediterranean populations of Ceratitis capitata (Wiedemann)
}

\author{
A Kourti ${ }^{1}$, P Hatzopoulos ${ }^{2}$ \\ 1 Agricultural University of Athens, Laboratory of Genetics; \\ 2 Agricultural University of Athens, Laboratory of Molecular Biology, Department \\ of Agricultural Biology and Biotechnology, Iera Odos, 75, 11855 Athens, Greece
}

(Received 28 February 1994; accepted 3 October 1994)

\begin{abstract}
Summary - Collections of Ceratitis capitata from 6 different areas from 4 Mediterranean countries were analysed for genetic variation. Six out of the 25 loci tested were found to be polymorphic. Allelic frequencies were estimated and the populations were found to be panmictic for 4 out of those 6 loci. Two of the polymorphic loci showed a significant clinal pattern in gene frequency changes by Spearman rank correlation with latitude. At 4 loci, a steep gradient in allele frequency (in Idh from 1.00 to 0.63 ) is observed in the axis of the north-south transect.
\end{abstract}

Ceratitis capitata / allelic frequency / cline

Résumé - Clines latitudinaux de fréquences alléliques dans des populations méditerranéennes de Ceratitis capitata (Wiedemann). Des échantillons de la mouche des fruits, Ceratitis capitata, provenant de 6 régions différentes de 4 pays méditerranéens, ont été examinés pour leur polymorphisme génétique à 25 locus enzymatiques. Six des locus se sont avérés polymorphes et les fréquences génotypiques observées à 4 de ces locus sont conformes à l'hypothèse de panmixie. Un cline latitudinal significatif des fréquences alléliques a été mis en évidence pour 2 de ces gènes polymorphes par un test de corrélation de rang de Spearman. Pour 4 locus, les variations de fréquences alléliques dans l'axe nordsud sont importantes, par exemple la fréquence de l'allèle 1.00 du gène Idh varie de 1,00 à 0,63 le long de cet axe.

Ceratitis capitata / fréquence allélique / cline 


\section{INTRODUCTION}

The Mediterranean fruit fly Ceratitis capitata is a polyphagous and multivoltine tropical and subtropical species, and one of the most serious pests of fruits and vegetables. During the last 150 years, medfly has been established in several countries including those of the Mediterranean basin from its proposed equatorial African origin (Fletcher, 1989). Even though the first report of this pest within the European Mediterranean area dates from the middle of the last century, the medfly has expanded throughout this basin because this region offers an increasing number of host fruits of different cultivars and/or species (De Breme, 1842; Martelli, 1910; Fimiani, 1989). Medfly is a serious threat to important fruit production centers throughout the world. However, the biology of this species is poorly known, especially its population genetics. Genetic variability might also provide information on the spread of $C$ capitata (Kourti et al, 1990; Gasperi et al, 1991). Recent results showed large genetic differences between introduced populations and those postulated to be their ancestral African ones. The average heterozygosity of medfly populations within the Mediterranean basin is about $5 \%$ versus $22 \%$ in the African populations (Huettel et al, 1980; Kourti et al, 1990; Gasperi et al, 1991). This significant heterozygosity of African populations (22\%) is comparable to that of other insect natural populations, eg, Drosophila (Ayala et al, 1972; Lewontin, 1974; Prakash, 1977; Hyytia et al, 1985). The similarity displayed in allele frequencies among medfly or Drosophila populations could be expected under the neutral theory, provided that some exchange of genetic material takes place between populations (Kimura and Marayama, 1971; Kimura and Ohta, 1971). In many cases, it was concluded that the subcosmopolitan status of medfly was recently achieved, due to human transport, and that any genetic divergence between geographically distant populations has occurred over a very short time. However, $C$ capitata appeared to be adapted to different environmental conditions, being able to constitute large populations in both the tropics and the temperate regions. Since the polymorphism of the introduced populations is low compared with that of their African counterparts, we focus our effort on elucidating this discrepancy among populations originating from different Mediterranean areas. This study was designed to detect latitudinal clines in gene frequencies. For this purpose, 6 natural populations from distantly located areas were examined.

\section{MATERIALS AND METHODS}

\section{Origin of populations}

Six populations of $C$ capitata from the Mediterranean basin were used in this study. The Spanish population was represented by a sample of pupae on peaches collected in October 1986 in the area of Castellon (S). The Greek populations were: a) from Attiki, where pupae were collected on peaches in July of 1986 (G1); and b) from the island of Crete, where pupae were also collected on peaches in July 1986 in the area of Chania (G2). The Israelian population was from the area of Best Dagan, where pupae were collected on apricots in June 1984 (I). The Egyptian populations were represented by 2 samples: a) pupae on apricots collected in May 1986 in the area of 
Kalubia (E1); and b) pupae on apricots collected the same period in the area of E1 Fayum (E2). Collections of wild flies from these Mediterranean populations were made by harvesting infested fruits from the ground. An effort was made to collect samples from 1 food source: the stone fruits (peaches or apricots).

\section{Electrophoretic studies}

The preparation of samples, and electrophoretic and staining procedures have been described by Kourti et al (1990). For each individual, 25 enzymes' loci were tested in the 6 populations. These were: $M p i$, To,Diaph-1 and Diaph-2, Adh, Ak, Odh, G-6-pd, 6-pgd, Idh, Hk-1, Hk-2, Got-1, Got-2, Fum, Est, Lap, Me, Mdh, Phi, Pgm, $\alpha-G p d h, P e p-1, P e p-2$ and Pep-3. From these the following enzymes were polymorphic: MPI, G-6-PD, IDH, PEP-1, PEP-2 and PEP-3. In a limited number of collections EST was also polymorphic.

\section{Statistics}

Chi-square tests were performed to compare observed numbers with those expected under Hardy-Weinberg equilibrium. The Chi-square test of the correlation between genes (Barker et al, 1986) was applied for loci with more than 2 alleles. The degree of relationship between clinal patterns was determined by Spearman rank correlation (Statgraph Statistical Program). The strategy is to look at conditional frequencies and their correlations with latitude as clinal measures.

\section{RESULTS}

The allelic frequencies at the 6 polymorphic loci, the collection sites and the number of individuals analysed are listed in table I. Most loci have 2 alleles with the exception of $G-6-p d$. All the peptidases are unmapped while the position of the other 3 loci is known (Malacrida et al, 1987). The $M p i$ and $P e p-1$ loci are polymorphic in all places, while the others were found monomorphic at least in 1 of the collection sites. In order to have a constant scoring and recording of data, the relative mobility of each allele was defined as previously described by Kourti et al (1990). The genotypes were pooled into 2 classes, homozygotes and heterozygotes in order to perform a uniform statistical comparison of observed versus expected genotypes. In table II, the numbers of homozygotes and heterozygotes observed are compared with the expected ones. Using the allelic frequencies determined at each locality, expected genotypic proportions (Hardy-Weinberg equilibrium) were compared with those observed (table II). The $\chi^{2}$ value is never significant for the biallelic loci, whereas in the case of G-6-pd 2 samples showed significant deviation from Hardy-Weinberg expectation. The correlation coefficient $r_{s}$ between the common allele frequency and latitude is given in table III. The Spearman rank correlation coefficient $\left(r_{s}\right)$ is given in table III. This analysis showed that 2 loci $G-6-p d$ and $I d h$ exhibit significant correlation between the common allele of these loci with latitude. Recent results obtained from only a few populations regarding Est polymorphisms also showed significant correlation (data not shown). 
Table I. Allelic frequencies of polymorphic loci in 6 Mediterranean populations of $C$ capitata classified by location in degrees north latitude.

Loci allele Spain $40^{\circ}$ Greece $138^{\circ}$ Greece $235^{\circ}$ Israel 32 ${ }^{\circ}$ Egypt $130^{\circ}$ Egypt $229^{\circ}$

\begin{tabular}{|c|c|c|c|c|c|c|}
\hline \multicolumn{7}{|c|}{$\begin{array}{l}\text { Chrom II } \\
\text { Mpi }\end{array}$} \\
\hline 1.00 & 0.162 & 0.052 & 0.085 & 0.208 & 0.317 & 0.375 \\
\hline 0.87 & 0.838 & 0.948 & 0.915 & 0.792 & 0.683 & 0.625 \\
\hline$n$ & 136 & 148 & 136 & 178 & 112 & 120 \\
\hline \multicolumn{7}{|c|}{ Chrom V } \\
\hline 1.02 & 0.031 & 0.034 & 0.040 & - & - & - \\
\hline 1.00 & 0.802 & 0.925 & 0.942 & 1.000 & 1.000 & 1.000 \\
\hline 0.98 & 0.167 & 0.041 & 0.018 & - & - & - \\
\hline$n$ & 96 & 148 & 136 & 80 & 80 & 80 \\
\hline \multicolumn{7}{|c|}{ Chrom VI } \\
\hline 1.00 & 1.000 & 1.000 & 1.000 & 0.728 & 0.707 & 0.633 \\
\hline 0.83 & - & - & - & 0.272 & 0.293 & 0.367 \\
\hline$n$ & 80 & 148 & 81 & 160 & 140 & 120 \\
\hline \multicolumn{7}{|c|}{$\begin{array}{l}\text { Loci unmapped } \\
\text { Pep-1 }\end{array}$} \\
\hline 1.26 & 0.524 & 0.470 & 0.662 & 0.442 & 0.489 & 0.535 \\
\hline 1.00 & 0.476 & 0.530 & 0.338 & 0.558 & 0.511 & 0.465 \\
\hline$n$ & 155 & 148 & 136 & 189 & 140 & 101 \\
\hline \multicolumn{7}{|c|}{ Рep-2 } \\
\hline 1.22 & - & - & 0.129 & - & 0.031 & 0.043 \\
\hline 1.00 & 1.000 & 1.000 & 0.871 & 1.000 & 0.969 & 0.957 \\
\hline$n$ & 118 & 148 & 136 & 189 & 80 & 81 \\
\hline \multicolumn{7}{|c|}{ Pep-3 } \\
\hline 1.06 & 0.278 & 0.158 & 0.125 & - & 0.011 & 0.005 \\
\hline 1.00 & 0.722 & 0.842 & 0.875 & 1.000 & 0.989 & 0.995 \\
\hline$n$ & 158 & 148 & 136 & 189 & 140 & 101 \\
\hline
\end{tabular}

Alleles in order of increasing anodal mobilities; $n$, number of individuals analysed. Populations according to country of origin. The numbers in the row below the countries represent latitudinal positions.

At the 2 loci, G-6-pd and $I d h$ showing significant correlations with latitude, the common allele frequencies exhibit a gradual change from different localities of collections, indicating the presence of a latitudinal cline (fig 1).

In all cases, there is a large frequency difference between the third site of collection (Crete) and fourth (Israel) (fig 1). The same difference in G-6-pd is smaller. In contrast, the frequency changes of the most common allele at the locus $M p i$ are rather smooth with the exception of the population collected from Spain (fig 1a). For loci showing the smallest frequency difference, Pep-1 and Pep-2, these are 1.1 and $4.3 \%$, respectively. The differences of loci that showed latitudinal clines, 
Table II. Comparison of observed (Obs) and expected (Exp) homozygous and heterozygous genotypes in the populations sampled.

\begin{tabular}{|c|c|c|c|c|c|c|}
\hline \multirow[t]{2}{*}{ Locality } & \multicolumn{2}{|c|}{ Homozygotes } & \multicolumn{2}{|c|}{ Heterozygotes } & \multirow[t]{2}{*}{$\mathrm{n}$} & \multirow[t]{2}{*}{$\chi^{2}$} \\
\hline & Obs & Exp & Obs & Exp & & \\
\hline \multicolumn{7}{|l|}{$M p i$} \\
\hline Spain & 96 & 99.07 & 40 & 36.93 & 136 & 0.97 \\
\hline Greece-1 & 133 & 134.75 & 15 & 13.25 & 148 & 0.03 \\
\hline Greece-2 & 115 & 114.85 & 21 & 21.15 & 136 & 0.00 \\
\hline Israel & 116 & 119.35 & 62 & 58.65 & 178 & 0.59 \\
\hline Egypt-1 & 67 & 63.51 & 45 & 48.49 & 112 & 0.58 \\
\hline Egypt-2 & 60 & 63.75 & 60 & 56.25 & 120 & 0.44 \\
\hline \multicolumn{7}{|l|}{$I d h$} \\
\hline Israel & 95 & 96.63 & 65 & 63.37 & 160 & 0.11 \\
\hline Egypt-1 & 80 & 82 & 60 & 58 & 140 & 0.17 \\
\hline Egypt-2 & 60 & 64.25 & 60 & 55.75 & 120 & 0.70 \\
\hline \multicolumn{7}{|l|}{ Pep-1 } \\
\hline Spain & 75 & 77.68 & 80 & 77.32 & 155 & 0.19 \\
\hline Greece-1 & 79 & 74.27 & 69 & 73.73 & 148 & 0.61 \\
\hline Greece-2 & 80 & 75.14 & 56 & 60.86 & 136 & 0.87 \\
\hline Israel & 92 & 95.77 & 97 & 93.23 & 189 & 0.31 \\
\hline Egypt-1 & 69 & 70.04 & 71 & 69.96 & 140 & 0.02 \\
\hline Egypt-2 & 47 & 50.75 & 54 & 50.25 & 101 & 2.73 \\
\hline \multicolumn{7}{|l|}{ Рep-2 } \\
\hline Greece-2 & 105 & 105.44 & 31 & 30.56 & 136 & 0.04 \\
\hline Egypt-1 & 75 & 75.25 & 5 & 4.75 & 80 & 0.09 \\
\hline Egypt-2 & 74 & 74.33 & 7 & 6.67 & 81 & 0.17 \\
\hline \multicolumn{7}{|l|}{ Pep-3 } \\
\hline Spain & 96 & 94.57 & 62 & 63.43 & 158 & 0.09 \\
\hline Greece-1 & 111 & 108.62 & 37 & 39.38 & 148 & 0.62 \\
\hline Greece-2 & 103 & 106.25 & 33 & 29.75 & 136 & 2.49 \\
\hline \multicolumn{7}{|l|}{$G-6 p d$} \\
\hline Spain & 74 & 64.5 & 22 & 31.48 & 96 & $11.32^{*}$ \\
\hline Greece-1 & 130 & 127.47 & 18 & 20.53 & 148 & 3.53 \\
\hline Greece-2 & 126 & 120.94 & 10 & 15.06 & 136 & $23.08^{*}$ \\
\hline
\end{tabular}

Number of individuals $=n . \mathrm{Chi}^{2}$ test with $1 d F .{ }^{*} p<0.001$

G-6-pd, Mpi, Pep-3 and Idh, are 19.9, 21.3, 27.3 and $36.7 \%$ respectively. The $M p i$ frequency difference between natural populations collected from Egypt and from Attiki is $33 \%$ and is one of the highest observed.

\section{DISCUSSION}

An extensive analysis has shown that the polymorphism (at least 16 genes out of 25) found in the African populations of $C$ capitata was high. However, only 6 loci out of these 25 were found polymorphic in the introduced populations of Mediterranean 
Table III. Spearman rank correlation coefficient $r_{\mathrm{s}}$ between the common allele frequency and degree of north latitude.

\begin{tabular}{lrc}
\hline & \multicolumn{1}{c}{$\mathrm{r}_{s}$} & Significance level \\
\hline$M p i$ & 0.829 & 0.064 \\
$G-6-p d$ & -0.941 & 0.035 \\
Idh & 0.941 & 0.035 \\
Pep-1 & 0.086 & 0.848 \\
Pep-2 & 0.516 & 0.248 \\
Pep-3 & -0.829 & 0.064 \\
\hline${ }^{*} p<0.001$ & &
\end{tabular}

medfly (Kourti et al, 1990). It is interesting to note that these 6 loci, $M p i, G-6-p d$, $I d h, P e p-1, P e p-2$ and $P e p-3$ maintain variants at substantial frequencies and from these, the frequencies of $M p i, G-6-p d, I d h$ and $P e p-3$ change steadily with latitude. When neighboring populations of a species are compared, one finds that they usually differ from one another, slightly or appreciably, in a number of characteristics, eg, size, color or any other morphological or physiological character (Halkka et al, 1975; Rhomberg and Singh, 1989). Huxley (1942) introduced the term 'cline' for such a character gradient. The gradual change of the common allele frequencies for at least these 4 loci corresponds to the latitudinal cline definition. However, only 2 loci, G-6-pd and $I d h$, have shown a significant $r_{\mathrm{s}}$. The cyclic behavior of $M p i$, found by Malacrida et al (1992) in another Mediterranean region (Italy), corroborates the results of the latitudinal cline observed through the Mediterranean basin. Alternatively, observed variations ( $i e \mathrm{Mp} i$ ) in allelic frequencies could be the combined effect of latitude and season. Several loci have been reported as latitudinally clinal in other insect natural populations. The list includes Est-6, $A d h, \alpha-G p d, G-6-p d, O d h, 6-P g d, A p h, E s t-C$, and Mdh (Voelker et al, 1977, 1978; Anderson, 1981; Oakeshott et al, 1981, 1982; David, 1982; Anderson and Oakeshott, 1984). The seasonal cycle in $M p i$ and the latitudinal clines of other loci suggest that alternative alleles have different optimal temperatures or other environmental variables (see also Tomiuk and Wohrmann, 1984). The working hypothesis is that the cline results from a geographically variable selective factor of the environment (Halkka et al, 1975). A concordance of clines for different characters is normally only found where ranges are essentially latitudinal and where the various environmental gradients (temperature and humidity for example) run more or less in a parallel way. The study of geographic variations has revealed that many of them are clinal. Clines are, ultimately, the product of 2 conflicting forces, selection, which would make every population uniquely adapted to its local environment, and gene flow, which would tend to homogenize all populations.

While some alleles sampled at high frequency in African populations are also found in Mediterranean populations, others, especially the uncommon ones, are locally or regionally lost (Kourti et al, 1990). This new pattern of allozyme frequency is maintained at a relatively stable level.

The contrast in polymorphism patterns between African and Mediterranean populations suggests that medfly polymorphism could be maintained by balancing 


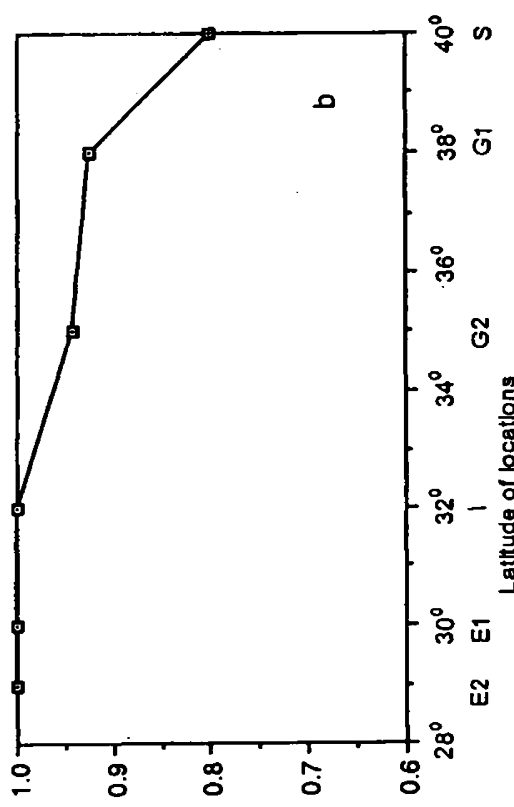

(00.l) pd-g-9 jo bast

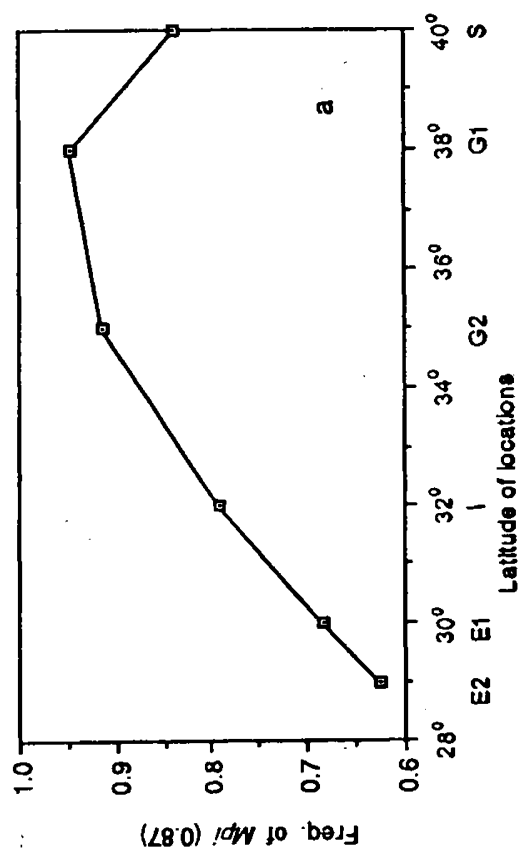

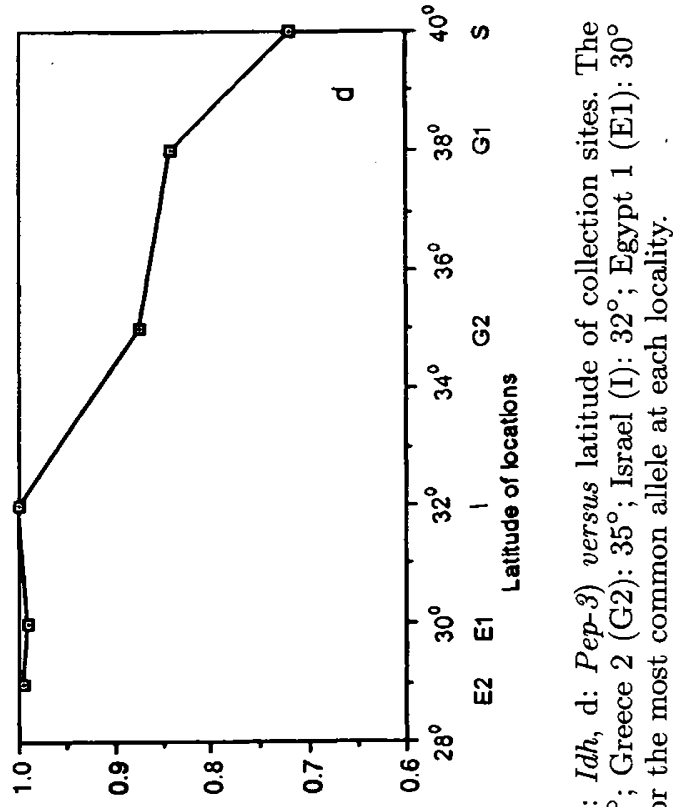

$\because \stackrel{\infty}{\circ}$

$\left(00^{\circ}\right.$ ) $\varepsilon$-dad to bosy

冬

ல่己

$\because$ 古

ف

纟:

范...

웡

으

总贾

结

它 导

ณ

若要

की

总。'

总过 응

过

造

灵苛

- 丞的

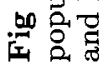


selection for which the equilibrium shifts with climate. Therefore the adaptively neutral or nearly neutral variation is expected to be purged, most likely by the repeated passage of local populations through bottlenecks (Kourti et al, 1990). Moreover, the lower polymorphism of Mediterranean populations compared with the African populations resembles the general pattern of marginal populations of a species submitted to genetic drift. Loci that are under rather strong balancing selection manage to maintain their total variability while others become monomorphic. Identification of such loci, however small in proportion, as in the case of medfly, may be more important than performing generalized tests of the neutral theory (Tomiuk, 1987). This explanation of widespread monomorphism, the difficulty of establishing and maintaining alleles expect by balancing selection, is an alternative to the hypothesis of broad adaptability of 'general purpose genotypes' (Parker et al, 1977; Angus and Schutz, 1979; Jaenike et al, 1980; Lynch, 1983).

Environment (latitude and/or season) could exert its force on allozyme frequencies. Since it is reasonable to expect that some loci might be important selective targets, and that there is a relationship between genotype and environment (often confirmed), as previously discussed, neutrality could not satisfactorily explain the data. Similar results have been reported for other natural populations (Johnson et al, 1969; Johnson and Schaffer, 1973; Voelker et al, 1978). In most cases there are correlations between allelic frequencies and environmental variables clearly favoring the selection hypothesis (Schaffer and Johnson, 1974).

In conclusion, the genetic latitudinal variations of $C$ capitata could be considered, as a whole, as a consequence of natural selection. Further studies, comparing tropical and temperate populations from other parts of the world, will determine whether such clines exist worldwide.

\section{ACKNOWLEDGMENTS}

We would like to thank $\mathrm{K}$ Krimbas for critical reading and attentive comments of this manuscript. AK is thankful to M Loukas for introducing her to the $C$ capitata system.

\section{REFERENCES}

Anderson PR (1981) Geographic clines and climatic association of Adh and $\alpha-G p d h$ gene populations Drosophila populations, frequencies in Drosophila melanogaster. In: Genetic Studies of Drosophila Populations (JB Gibson, JG Oakeshott, eds), Australian National University, Camberra, Australia, 237-250

Anderson PR, Oakeshott JG (1984) Parallel geographic patterns of allozyme variation in two sibling species. Nature (Lond) 308, 729-731

Angus RA, Schutz RJ (1979) Clonal diversity of the unisexual fish Poeciliopsis monachalucida: a tissue graft analysis. Evolution 33, 27-40

Ayala FJ, Powell R, Tracey ML, Mourao CA, Peter-Saaly S (1972) Enzyme variability in the $D$ willistoni group. IV. Genic variation in natural populations of $D$ willistoni. Genetics 70, 113-139

Barker JSF, East PD, Weir BS (1986) Temporal and microgeographic variation in allozyme frequencies in a natural population of Drosophila buzzati. Genetics 112, 577-611

David JR (1982) Latitudinal variability of Drosophila melanogaster: allozyme frequencies divergence between European and Afrotropical populations. Biochem Genet 20, 747-761 
De Breme F (1842) Note sur le genre Ceratitis de M Mac heay (Diptera). Ann Soc Entomol (France) 11, 183-190

Fimiani P (1989) Mediterranean Region. In: Fruit Flies: Their Biology, Natural Enemies and Control (AS Robinson, G Hooper, eds), Elsevier, Amsterdam, The Netherlands, Vol 3A, 37-50

Fletcher BS (1989) Life history strategies of tephritid fruit flies. In: Fruit Flies: Their Biology, Natural Enemies and Control (AS Robinson, G Hooper, eds), Elsevier, Amsterdam, The Netherlands, Vol 3B, 195-208

Gasperi G, Guglielmino CR, Malacrida AR, Milani R (1991) Genetic variability and gene flow in geographical populations of Ceratitis capitata (Wied) (medfly). Heredity 67, $347-356$

Halkka O, Raatikainen M, Vilbaste J (1975) Clines in the colour polymorphism if Philaenus spumarius in Eastern Central Europe. Heredity 35, 303-309

Huettel MD, Fuerst PA, Maruyama M, Chakraborty R (1980) Genetic effects of multiple population bottlenecks in the Mediterranean fruit fly (Ceratitis capitata). Genetics $94 \mathrm{~s}$, $47-48$

Huxley J (1942) Evolution the Modern Synthesis. Allan and Unwin, London, UK

Hyytia P, Capy P, David JR, Singh RS (1985) Enzymatic and quantitative variation in European and African populations of Drosophila simulans. Heredity 54, 209-217

Jaenike J, Parker ED, Selander RK (1980) Clonal niche structure in the parthenogenetic earthworm Octolasion tyrtaeum. Am Nat 116, 196-205

Johnson FM, Schaffer HE, Gillaspy JE, Rockwood ES (1969) Isozyme-genotype relationships in natural populations of the harvester ant, Pogonomyrmex barbatus, from Texas. Biochem Genet 3, 429-450

Johnson FM, Schaffer HE (1973) Isozyme variability in species of the genus Drosophila. VII. Genotype environment relationships in populations of $D$ melanogaster from the eastern United States. Biochem Genet 10, 149-163

Kimura M, Marayama T (1971) Pattern of neutral polymorphism in a geographically structured population. Genet Res 18, 125-131

Kimura M, Ohta T (1971) Protein polymorphism as a phase of molecular evolution. Nature (Lond) 229, 467-469

Kourti A, Loukas M, Economopoulos AP (1990) Population genetics of the Mediterranean fruit fly, Ceratitis capitata (Wied). In: Genetic Sexing of the Mediterranean Fruit Fly, IAEA, Panel Proceedings Series, Vienna, Austria, 7-32

Lewontin RC (1974) The Genetic Basis of Evolutionary Change. Columbia Univ Press, New York, USA

Lynch M (1983) Ecological genetics of Daphnia pulex. Evolution 37, 358-374

Malacrida AR, Gasperi G, Milani R (1987) Genome organization of Ceratitis capitata: linkage groups and evidence for sex-ratio distorders. In: Fruit Flies (AP Economopoulos, ed), Elsevier Science Publishers, Amsterdam, The Netherlands, 169-174

Malacrida AR, Guglielmino RC, Gasperi G, Baruffi L, Milani R (1992) Spatial and temporal differentiation in colonizing populations of Ceratitis capitata. Heredity 69, 101-111

Martelli G (1910) Aleune note intorno ai costumi e ai danni della Mosca delle orance (Ceratitis capitata, Wied). Bol Lab Zool Agr Portici 4, 120-127

Oakeshott JG, Chambers GK, Gibson JB, Willcocks DA (1981) Latitudinal relationships of esterase-6 and phosphoglucomutase gene frequencies in Drosophila melanogaster. Heredity 47, 385-396

Oakeshott JG, Gibson JB, Anderson PR, Knibb WR, Anderson DG, Chambers GK (1982) Alcohol dehydrogenase and glycerol-3-phosphate dehydrogenase clines in Drosophila melanogaster on different continents. Evolution 36, 86-96 
Parker ED, Selander RK, Hudson RO, Lester J (1977) Genetic diversity in colonizing parthenogenetic cockroaches. Evolution 31, 836-842

Prakash S (1977) Genetic divergence in closely related sibling species Drosophila pseudoobscura, Drosophila persimilis and Drosophila miranda. Evolution 31, 14-23

Rhomberg LR, Singh RS (1989) Evidence for a link between local and seasonal cycles in gene frequencies and latitudinal gene clines in a cyclic parthenogen. Genetica 78, 73-79

Schaffer HE, Johnson FM (1974) Isozyme allelic frequencies related to selection and geneflow hypothesis. Genetics $77,163-168$

Tomiuk J (1987) The neutral theory and enzyme polymorphism in populations of Aphid species. In: Population Structure, Genetics and Taxonomy of Aphids and Thysanoptera (J Holiman, J Pelican, AFG Dixon, L Weismann, eds), SPB Academic Pub, London, UK, 45-62

Tomiuk J, Wohrmann K (1984) Genotypic variability in natural populations of Macrosiphum rosae (L). Eur Biol Zbl 103, 113-122

Voelker RA, Mukai T, Johnson FM (1977) Genetic variation in populations of Drosophila melanogaster from the western United States. Genetica 47, 143-148

Voelker RA, Cockerham CC, Johnson FM, Shaffer HE, Mukai T, Mettler LE (1978) Inversions fail to account for allozyme clines. Genetics 88, 515-527 